\title{
Delik Pers dalam Perspektif Undang-Undang Perlindungan Konsumen
}

\author{
Samsul Wahidin
}

\begin{abstract}
Although consumers Protection Act regulated on protection upon consuption goods, not all of them are protected. And even though press products can be qualified as consumption goods (such as information), the legal protection is based on the provisions of Press Act. With regard to press consumption, Consumers Protection Act is not Applicable
\end{abstract}

\section{Pendahuluan}

UU tentang Perlindungan Konsumen (UU No. 8 Tahun 1999) secara yuridis mengatur tentang seluk-beluk hubungan antara pemakai penyedia dengan pemakai barang dan/atau jasa yang tersedia dalam masyarakat baik bagi kepentingan diri sendiri, keluarga, orang lain maupun makhluk hidup lain dan tidak untuk diperdagangkan. Dengan hubungan hukum terśebut intinya agar tidak menimbulkan kerugian khususnya pada konsumen sehingga hubungan antara konsumen dan produsen tidak bersifat subordinat tetapi sejajar atas dasar saling membutuhkan, sesuai dengan prinsip-prinsip hubungan yang berkesetaraan atau sekurangnya konsumen tidak dirugikan.

UU ini mulai berlaku efektif pada 20 April 1999 yang diharapkan dapat dijadikan sebagai landasan bagi tujuan sebagaimana dimaksud. Penekanan terhadap institusi yang disebut sebagai suatu perlindungan hukum (legal protection)' tercermin pada judul UU itu sendiri yang secarajelas menitikberatkan pada upaya untuk meningkatkan harkat dan martabat konsumen, meningkatkan kesadaran dan pengetahuan, kepedulian, kemampuan dan kemandirian konsumen untuk melindungi dirinya serta menumbuhkembangkan sikap pelaku usaha yang bertanggung jawab (dișebutkan dalam konsideran huruf (d) UU No. 8 Tahun 1999).

Lima bulan kemudian pemerintah bersamasama dengan DPR berhasil membuat produk hukum baru di bidang pers yaitu UU No. 40 tentang Pers (UU No.40 Tahun 1999) yang

'Legal Protection (perlindungan hukum) pada umumnya berhubungan dengan kekuasaan dan'kekuatan pemerintah pada satu sisi, dan rakyat yang identik dengan ketakberdayaan pada sisi lain. Lihat: Philipus $M$. Hadjon, 1987. Perlindungan Hukum Bagi Rakyat di Indonesia. Surabaya: Bina llmu. Him. 1. 
menjadi landasan hukum bagi kinerja pers. UU ini juga mengakomodasikan pertindungan hukum bagi masyarakat dalam hal konsumen pers yang menjadi sasaran dan obyek sajian. Secara umum hakekat pers juga dapat dipandang sebagai satu produk konsumsi, karena di dalamnya juga terjadi interaksi antara penjual dan pembeli kendati pun barang yang dikonsumsi tersebut sasarannya bukan fisik manusia. ${ }^{2}$

Dengan demikian, pers merupakan realisasi dari hak atas informasi yang menjadi bagian dari hak konsumen. Paling tidak jika hal itu dipandang sebagai adanya keharusan hubungan yang bersifat kesetaraan, tidak subordinat seperti disyaratkan oleh UUPK. Memberi arti pada UU Perlindungan Konsumen (UUPK) secara jelas juga mengakomodasikan pertindungan hukum kepada seluruh jenis barang konsumsi. Jelas di dalam wacana sosiologis dapat dikatakan bahwa para pembaca, pemirsa atau pendengar adalah konsumen. ${ }^{3}$ Para pihak yang terikat dengan institusi pemroduksi adalah sebagai produsennya. Ketika mencermati ketentuan dalam UU tentang Pers, ternyata perlindungan hukum yang sama diberikan yang akan dijadikan sebagai rambu di dalam kinerja lembaga pers. Ketika muncul sajian pers bermasalah, permasalahannya adalah hak konsumen (pers) itu mesti didasarkan pada ketentuan yang mana? Apakah UUPK berlaku untuk konsumen pers? UU tentang Pers, seperti disebut di dalam Ketentuan Umum berlaku untuk seluruh jenis komunikasi massa baik berbentuk tulisan, suara, gambar, suara dan gambar (audiovisual) serta data dan grafik maupun dalam bentuk lainnya dengan menggunakan media cetak, media elektronik dan segala jenis saluran yang tersedia. Kendatipun secara harfiah arti konsumen (consumer) adalah pemakai, namun di AS misalnya, diartikan secara lebih luas yaitu sebagai korban pemakaian produk cacat.

\section{Konsumen dalam UUPK}

Beberapa ahli di dalam hukum konsumen. melakukan analisis ${ }^{4}$ yang secara argumentatif berupaya mengaitkan soal tanggung jawab pelaku usaha pers berdasarkan UUPK tersebut. Dari analisis yang disampaikan di dalam pengaitan antara UUPK dengan UU Pers tersebut dapat ditarik kesimpulan bahwa atas tanggung jawab pelaku usaha pers berdasar UU Pers dapat dituntut secara hukum. Juga disimpulkan bahwa UU Perlindungan Konsumen adalah usaha untuk melindungi konsumen dalam menghadapi era kebebasan pers saat ini.

Dengan demikian jika ada korban dari sajian pers mengajukan tuntutan, maka UUPK dapat dijadikan sebagai dasar hukum.

'Empat hak konsumen sebagaimana dikemukakan oleh presiden AS JF Kennedy adalah: the right to safety, the right to choose, the right to informed dan the right to be heard. Lihat: Agus Brotosusilo. 1998. "Aspeks-Aspek Perlindungan Terhadap Konsumen dalam Sistem Hukum di Indonesia" Makalah. Jakarta: YLKI-USAID. HIm. 49.

3/bid. hal. 40.

${ }^{4} \mathrm{M}$. Said Sutomo. 2000. "Hak Gugat Konsumen Terhadap Perilaku Usaha Pers." Opini Harian Surya Surabaya. Rabu 28 Juni $2000 . \mathrm{HIm}$. 17. 
Konkretnya, UUPK dapat dijadikan sebagai dasar komplain terhadap sajian pers bermasalah yang dinilai membawa kerugian baik moral maupun materiil terhadap konsumen (sajian pers). ${ }^{5}$ Ketentuan yang dapat dijadikan sebagai dasar penuntutan adalah sebagaimana disebutkan di dalam Pasal 61 UUPK yang secara rinci mengakomodasikan hak-hak konsumen yang dirugikan. Apabila ternyata pelaku usaha terbukti melanggar ketentuan di dalam UUPK tersebut, maka dapat dijatuhi pidana berupa pidana maksimal 5 tahun atau pidana denda maksimal 2 milyar rupiah.

\section{Perspektif Pers}

Di dalam perspektif asas hukum yang secara universal dijadikan sebagai pedoman analisis, dapat disimpulkan bahwa pengaitan antara UUPK dan UU Pers dalam soal perlindungan konsumen itu mengandung satu kekeliruan konsep (absurd in concepto), atau mengandung kesesatan (fallacies) 5 yang berakibat pada tidak tercapainya nilai kebenaran dan keadilan di dalam penegakan hukum, khususnya bagi para konsumen pers.

. Tesis atas terjadinya kesesatan di dalam penerapan ketentuan sehubungan dengan posisi UUPK dikaitkan dengan UU Pers dimaksud, setidaknya ada 2 (dua) hal yang bersifat konseptual dan oleh karena itu perlu diluruskan. Pertama menyangkut eksistensi UUPK di dalam kerangka perlindungan konsumen dan kedua menyangkut tanggung jawab atas sajian pers sehubungan dengan perlindungan terhadap konsumen pers baik diakibatkan oleh sajian yang tidak benar maupun kerugian yang harus ditanggung oleh sumber sajian dan atau obyek sajian. Pada masalah pertama, eksistensi UUPK memang untuk melindungi konsumen dari perlakuan tidak adil khususnya oleh produsen. UU itu tidak dimaksudkan sebagai instrumen yang dapat menjangkau segala hal yang menyangkut segi-segi perlindungan hukum terhadap konsumen.

Kendatipun ada perluasan makna sehubungan dengan perlindungan hukum tersebut, minimal tidak untuk masalahmasalah yang bersifat khusus sebagaimana diatur oleh UU yang bersangkutan. UUPK ditujukan untuk melindungi konsumen misalnya dalam perkara consumer's good. ${ }^{6}$ UUPK dengan demikian dapat dipandang sebagai satu ketentuan yang sifatnya generalis di dalam masalah barang konsumsi secara umum. Penegasan ini juga disampaikan di dalam Penjelasan Umum UUPK yang menyebut ada 20 Undang-Undang yang secara materiil juga memberi perlindungan terhadap konsumen. Perlindungan tersebut adalah sesuai dengan materi UU yang bersangkutan. Keduapuluh Undang-undang itu dinyatakan sebagai ketentuan yang mengakomodasikan perlindungan konsumen dan tetap berlaku tidak secara khusus diatur di dalam UUPK.

Secara argumentum a contrario, maka UUPK tidak berlaku jika ada ketentuan yang bersifat specialis. Hal ini sesuai dengan asas

${ }^{5}$ PM Hadjon 1994. Pengkajian IImu Hukum (Dogmatik Normatif). Surabaya: Fakultas Hukum Unair. HIm. 20.

'Ujang Sumarwan. 1998. Masalah Keamanan Pangan dalam Pola Konsumsi Masyarakat Indonesia. Jakarta:YLKI-USAID. HIm. 73. 
lex specialis yang berbunyi lex specialis derogat legi generalis. ${ }^{7}$ Maksudnya bahwa ketentuan yang bersifat khusus mengenyampingkan ketentuan umum. Artinya sepanjang memang memberikan gambaran bagaimana masih rawannya keamanan pangan (barang yang langsung dikonsumsi) pada masyarakat Indonesia.hal itu tidak diatur di dalam ketentuan khusus, maka UUPK berlaku dan dapat dijadikan sebagai landasan hukum mengajukan tuntutan dan atau gugatan.

Pencermatan mengenai tidak berlaku atau tidak dapat diterapkannya UUPK ini pada konsumen pers juga dapat disimak di dalam Penjelasan Umum UUPK. Dari 20 (dua puluh) jenis UU yang disebut di dalamnya, dan mengukuhkan UUPK sebagai umbrella provision (payung pelindung) ${ }^{8}$ bagi konsumen ternyata tidak dicantumkan adanya Pers sebagai UU yang berada di bawah lindungannya. Kalaupun ada disebutkan di dalam penjelasan itu UU No. 24 Tahun 1999 yaitu tentang Penyiaran, maka penyebutan itu masih harus dipersoalkan dalam bidang mana konsumsi tersebut beriaku. Demikian pula di dalam Penjelasan Umum itu sendiri juga dikemukakan bahwa bukan mustahil di kemudian hari akan ada ketentuan-ketentuan baru yang melindungi konsumen. UU demikian justru akan menjadi pelengkap dari UUPK.

Dengan dikukuhkannya UU No. 40 Tahun 1999 yang secara tegas mematok media audio dan audiovisual sebagai bagian dari pers semakin jelas bahwa pencantuman UU tentang Penyiaran di dalam kerangka UU Perlindungan Konsumen itu memperkuat maknanya sebagai lembaga perlindungan hukum pada consumer's good. Khusus tentang UU No. 24 Tahun 1997 sebagaimana disebut di dalam Penjelasan Umum UUPK, dapat dikembalikan berdasarkan asas Posterior. Lexposterior derogat legi priori, ${ }^{9}$ artinya bahwa UU yang datang kemudian mengalahkan UU terdahulu. Hal ini dipertegas oleh ketentuan Pasal 19 ayat (1) UU Pers yang menegaskan: Dengan berlakunya UU ini segala peraturan perundang-undangan di. bidang pers yang berlaku serta badan atau lembaga yang ada tetap berlaku atau tetap menjalankan fungsinya sepanjang tidak bertentangan atau belum diganti dengan yang baru berdasarkan' UU ini. Dengan demikian, konsumen sajian media elektronik baik yang bersifat audio maupun audiovisual juga tidak dapat menuntut berdasarkan UUPK.

Pihak yang merasa dirugikan oleh sajian media tersebut dapat melakukan penuntutan berdasarkan UU Pers. Sebab di dalam ketentuan UU Pers itu jelas menyebut bahwa yang dimaksudkan dengan pers itu pada dasarnya tidak hanya pers cetak. Termasuk di dalam pengertain pers itu juga pers elektronik yang meliputi audio (radio) dan audiovisual (televisi). Kendatipun UUPK berposisi sebagai umbrella provision, tetapi di dalam penerapan hukumnya bersifat komplementer. Artinya sepanjang didalam UU yang bersifat khusus tidak mengatur barulah diterapkan UUPK yang akan melengkapi berbagai ketentuan yang

'PM. Hadjon. Op.Cit. HIm. 26.

¿Dapat dilihat pada alinea terakhir dari Penjelasan Umum UUPK

9PM. Hadjon. Op.Cit. 
disebutkan di dalam Penjelasan Umum termasuk UU yang akan datang nanti.

\section{Tanggung Jawab terhadap Konsumen Pers}

Tanggung jawab terhadap konsumen pers dimaksudkan sebagai satu mekanisme hukum ${ }^{10}$ untuk mengkonstruksi siapa yang harus menanggung risiko atas klaim sebagai akibat dari produk konsumsi (pers) yang tidak benar. Termasuk di dalam ketentuan mana yang dapat dijadikan sebagai dasar hukum klaim dimaksud.

Berdasarkan argumentasi yang telah dikemukakan pada hal-hal yang berkait dengan tanggungjawab terhadap sajian pers lebih memperjelas bahwa dalam hal terjadinya sajian pers bermasalah yang akibatrya menimbulkan kerugian pada konsumen pers itu tidak dapat diteraṕkan UUPK. Soainya untuk pers telah ada instrumen hukumnya yaitu UU tentang Pers (UU No. 40 Tahun 1999). Di dalam UU ini secara khusus mengatur tentang mekanisme hukum seputar tanggung jawab yang secara langsung juga berarti perlindungan hukum kepada masyarakat sebagai konsumen pers dari sajian yang dinilai merugikan. Masyarakat; di dalam interaksinya dengan pers diberikan pedoman"1 tentang apa saja yang dapat dilakukan sehubungan dengan sajian pers yang tidak benar baik dalam kapasitasnya sebagai sumber atau obyek sajian maupun sebagai pembaca.

Mencermati di dalam UU tentang Pers di Indonesia sebelum UU Pers yaitu dalam UU No. 21:Tahun 1982 memang belum ada perlindungan hukum yang boleh disebut memadai. Ada berbagai kasus klaim yang diajukan oleh pihak yang merasa dirugikan atas dasar $U U$ tersebut terhadap pers melalui mekanisme hukum yang ada ternyata masih belum sampai ke pengadilan. ${ }^{12}$ Ada banyak alasan mengapa di Indonesia termasuk langka misainya dalam hal terjadinya delik pers (pers delict). Satu alasan menyebut adanya semacam jalinan konspirasi antara pers dengan aparat penegak hukum dengan berlindung di balik tema-tema kemitraan. ${ }^{13}$ Ada pula yang menyebut dalam batas tertentu muncul keengganan aparat menindak si wartawan disebabkan oleh kenyataan bahwa di dalam tubuh aparat penegak hukum sendiri juga ada cacat yang menginventarisir berbagai kasus

:Mekanisme hukum dimaksudkan sebagai istilah agar tidak rancu dengan pengertian hukum sebagai sistem yang merupakan istilah baku untuk menggambarkan kinerja hukum secara luas yaitu di dalam masyarakat. Lihat: Lili Rasyidi. IB. Wiyasa Putra. 1993. Hukum Sebagai Suatu Sistem. Bandung. Remaja Roosdakarya

"Dasiar pedoman dimaksud adalah Undang Undang yang secara positif berlaku dan dapat dilaksanakan.

${ }^{12}$ Contoh kasus antara Probosutedjo-majalah TEMPO, Abdul Latief (Menteri Tenaga Kerja)-Tabloid Paron, kasus Sampul majalah D\&R, KISDI-Harian Kompas, IPTN-The Jakarta Post dan sebagainya adalah contoh kasus klaim terhadap pers yang tidak sampai ke pengadilan. Sementara itu juga tidak kurang dari 30 kasus kekerasan terhadap jurnalis sepanjang tahun 1997 khususnya menjelang Pemilu tidak diselesaikan secara hukum. Lihat: Aliansi Jurnalis Independen. 1998. Pers Diterpa Krisis. Jakarta. AJI-LSPP. HIm. 37.

${ }^{13}$ Samsul Wahidin. 1999. "Tanggung Jawab Atas Pemberitaan Pers Dalam Media Cetak." Disertasi. Surabaya. PPS Unair. HIm. 143. 
kekerasan terhadap wartawan selama menjalankan tugas pada Pemilu di tahun 1997 tersebut yang pada satu ketika dapat menjadi komoditas pemberitaan pers - bahkan menjadi bulan-bulanan kalau pers merasa diperlakukan tidak nyaman.

Satu alasan yang signifikan dan dapat dipertanggungjawabkan secara yuridis adalah adanya kelemahan di dalam mekanisme pertanggungjawaban sajian pers dalam UU Pers yang lalu (UU No. 21 tahun 1982 tentang Ketentuan Ketentuan Pokok Pers). Kelemahan itu berkisar pada kesulitan aparat penegak hukum untuk menerjemahkan secara konkret tentang siapa yang harus memikul tanggung jawab atas sajian pers. Soalnya di dalam UU itu pertanggungjawaban dapat dilimpahkan kepada pihak lain yaitu anggota redaksi lain dan atau penulisnya. ${ }^{14}$ Konsep tanggung jawab yang dapat dilimpahkan ini dikenal dengan waterfall system atau pertanggungjawaban yang bersifat suksesif. ${ }^{15}$ intinya adalah bahwa Pemimpin Umum dapat memindahkan tanggung jawab terhadap kepada Pemimpin Redaksi. Pemimpin Redaksi dapat memindahkan tanggung jawab terhadap hukum kepada Redaksi yang lain atau kepada Penulis yang bersangkutan. Di dalam dimensi keadilan, sistem pertanggungjawaban demikian tidak sesuai dengan asas di dalam hukum (pidana) yang menyatakan bahwa siapa yang bersalah maka ia harus memikul kesalahan tersebut beserta dengan akibatnya. Sementara akan merupakan satu ketidakadilan jika akibat suatu perbuatan harus ditanggung oleh orang lain yang tidak melakukannya. ${ }^{16}$ Oleh karena ketidakjelasan inilah yang menjadi salah satu kendala sulitnya membawa kasus kerugian konsumen pers ke pengadilan. Pihak yang merasa dirugikan, demikian pula aparat penegak hukum ragu untuk bertindak disebabkan tidak jelas subyek mana yang seharusnya bertanggungjawab. Apakah kualifikasi itu harus dikenali sejak akan mengadukan apakah nanti setelah pemeriksaan dilakukan? Permasalahan yang tidak terjawab ini merupakan kesulitan utama penegakan hukum sebagai akibat kerugian yang menimpa pada konsumen pers. ${ }^{17}$

Di dalam UU Pers yang baru ini, ada 3 (tiga) kualifikasi pelanggaran yang menyebabkan dijatuhkannya sanksi kepada penerbitan pers. Ketiga hal tersebut jika dirinci maka satunya menyangkut perlindungan hukum terhadap kinerja pers dan dua lainnya menyangkut perlindungan hukum kepada konsumen pers. Dengan demikian dalam hal yang kedua dan ketiga inilah yang dapat dijadikan sebagai dasar hukum penuntutan terhadap pers.

Adapun kualifikasi pertama adalah merupakan akomodasi dari proteksi atau perlindungan hukum terhadap kinerja pers. Di dalam ketentuannya mematok sanksi yang dijatuhkan kepada penghambat penerbitan pers yang di dalam UU itu diproteksi bahwa tidak dikenakan sensor dan breidel. Siapa saja, dari aparat pemerintah atau kelompok masyarakat yang menghambat atau

${ }^{14}$ Disebutkan di dalam Pasal 15 UU No.21/1982

${ }^{15}$ Mustafa Abdullah. 1998. "Sistem Pertanggungjawaban Pidana Pers Menurut Hukum Positif di Indonesia." Pidato Pengukuhan Guru Besar FH Universitas Sriwijaya. Palembang. Universitas Sriwijaya. HIm. 13. ${ }^{16}$ Samsul Wahidin. Op.Cit. HIm. 176

${ }^{17}$ Samsul Wahidin, 2000. "Tanggungjawab Hukum Atas Sajian Pers." Surat Kabar Harian Surya. HIm. 17. 
menghalangi penerbitan pers secara melawan hukum, melakukan perbuatan yang mengarah kepada breidel dan sensor akan dijatuhi sanksi pidana. Asalkan pihak pers dapat membuktikan terjadinya hambatan, sensor dan breidel tersebut. ${ }^{18}$ Pola pikir atas dicantumkannya sanksi ini erat berkait dengan perlindungan terhadap HAM khususnya hak untuk mengeluarkan pendapat. Atas dasar kebebasan untuk mengeluarkan pendapat tersebut, salah satunya adalah dengan melalui media informasi dan salah satu media informasi adalah melalui pers. Di dalam sistem pers di Indonesia, hak tersebut diproteksi dengan adanya perlindungan hukum terhadap profesi yang secara khusus menekuni bidang informasi. Dengan demikian diharapkan tidak akan terjadi tindak sewenang-wenang atau bahkan juga tindak kekerasan terhadap subyek hukum yang menekuni profesi tersebut.

Proteksi yang secara jelas diperuntukkan bagi warga masyarakat terhadap arogansi pers adalah berupa pelanggaran redaksional yaitu sajian pers yang ternyata tidak menghormati norma-norma agama dan rasa kesusilaan masyarakat serta mengabaikan asas praduga tak bersalah. Juga termasuk dalam kelompok ini, kebijakan redaksional yang tidak memuat Hak Jawab serta pers yang memuat iklan yang melanggar etika periklanan seperti mengiklankan obat-obat terlarang, iklan yang mengganggu kerukunan hidup antarumat beragama dan sebagainya. ${ }^{19}$ Proteksi ini. sifatnya adalah komunitas dalam arti tidak harus menyangkut subyek hukum perorangan. Secara teknis pengajuan gugatan dapat disampaikan secara class action atau melaluj lembaga tertentu yang secara khusus bergerak di dalam bidang ini. Misalnya Media Watch, sebagaimana disebutkan di dalam Penjelasan Umum UU No. $40 / 1999$ yang diharapkan dapat berfungsi sebagai lembaga pengawas kinerja pers. Sekaligus dapat mewakili masyarakat jika temyata sajian pers dinilai tidak sesuai dengan ketentuan dimaksud.

Dalam perspektif yuridis, kiranya di dalam ketentuan inilah yang dapat dijadikan sebagai dasar hukum materiil di dalam mengajukan klaim terhadap sajian pers. Sedangkan apa saja yang termasuk di dalam ketentuan tentang iklan yang melanggar etika dan sebagainya itu diserahkan pada perkembangan masyarakat setempat atas penilaian mereka terhadap masalah itu.

Ketiga, penerbitan pers yang tidak berbadan hukum dan secara teknis tidak beridentitas. Identitas di sini maksudnya tidak mengumumkan jati diri penanggung jawab secara terbuka melalui media bersangkutan dan untuk penerbit tidak mencantumkan nama

${ }^{18}$ Pasal 18 UU No. 40 tahun 1999 menjatuhkan sanksi penjara maksimal 2 (dua) tahun atau denda maksimal Rp 500 juta bagi siapa saja yang secara melawan hukum menghambat atau menghalangi pelaksanaan tugas pers. Hak Jawab merupakan hak dari pihak yang merasa dirugikan dan harus dipublikasikan sesuai dengan syarat-syarat tertentu. Materi Hak Jawab terlepas dari pendapat dan keyakinan redaksi tentang kebenarannya. Artinya kendatipun sebenamya redaksi merasa yakin bahwa materi Hak Jawab itu tidak benar tetap harus dipublikasikan, sepanjang memenuhi syarat teknis redaksional.

${ }^{19}$ Disebutkan dalam Pasal 18 ayat (2) UU No. 40/1999. 
dan alamat percetakan. Hal ini dimaksudkan sebagai proteksi terhadap pertanggungjawaban materi jika nantinya dinilai bermasalah.

Menyimak sistem pertanggungjawaban dalam UU Pers dapat disimpulkan bahwa pertanggungjawaban yang diterapkan adalah atas dasar gerant responsible ${ }^{20}$ atau sistem pertanggungjawaban manajer. Inti dari pertanggungjawaban ini adalah bahwa sanksi dijatuhkan gerant atau manajer yang harus bertanggung jawab terhadap semua perbuatan yang diancamkan terhadap pelanggaran yang dilakukan personal penerbitan ${ }^{21}$ (vide Pasal 18 ayat (2)). Konkretnya, pertanggungjawaban harus dipikul oleh pemimpin redaksi. Sementara anggota redaksi dan seterusnya, termasuk jajaran perusahaan dapat dituntut berdasar mekanisme dalam konstruksi pertanggungjawaban pidana konvensional.

Dalam hal ini jelas kepada siapa subjek tuntutan dan atau gugatan harus dialamatkan. Mekanisme pertanggungjawaban itu sejalan dengan kebijakan tentang pengawasan pers yang pelaksanaannya diserahkan pada internal pengelola dan khalayak pembaca. Bukan lagi pada pemerintah seperti masa lalu yang meletakkan hubungan subordinat antara pemerintah-pers. Pers, kendatipun diatur secara khusus akan tetapi tetap dipandang sebagai instrumen yang bersifat umum perkembangan dan batas-batasnya diserahkan kepada interaksi antara pers dengan masyarakat yang tumbuh dan berkembang secara alami dan tidak kalah pentingnya pada kontrol internal dari pers itu sendiri: ${ }^{22}$ Adapun teknis pengaduan atas klaim konsumen pers dapat disampaikan melalui pengadilan perdata, pidana atau melalui asosiasi profesi. Dalam hal pengadilan perdata jelas bahwa dasar gugatannya adalah ketentuan yang ada di dalam KUHPerdata. Melalui pengadilan Pidana adalah dengan melalui pengaduan kepada pihak berwajib. Pengaduan melalui organisasi profesi yaitu dengan melayangkan pengaduan kepada induk organisasi yang bersangkutan ${ }^{23}$ (misalnya untuk $\mathrm{PWl}$ adalah Dewan Kehormatan Pers). Organisasi ini secara profesional akan mengambil keputusan tentang benar atau tidaknya standar profesionalisme yang dijadikan acuan oleh pekerja pers terhadap sajian yang dianggap bermasalah. Jika memang terbukti tidak sesuai dengan standar profesionalisme maka kepada wartawan dan atau penerbit akan dikenai sanksi sesuai dengan aturan yang secara internal dipatok.

Penyelesaian melalui asosiasi profesi ini tidak menutup kemungkinan diselesaikannya lebih lanjut berdasarkan hukum. Pihak yang

\footnotetext{
${ }^{20}$ Samsul Wahidin. 2000. Perspektif Hukum Tanggungjawab Pers. Makalah disampaikan pada Seminar. Pers-YLKI. Banjarmasin. 20 Juni 2000.

2Mustafa Abdullah, Op.Cit. HIm. 7.

${ }^{22}$ Berbagai penerbitan yang sudah mapan mempunyai lembaga semacam Ombudsmen yang secara khusus melayani tiap klaim dari masyarakat sebagai alternatif penyelesaian perkara di luar pengadilan.

${ }^{23}$ Sampai pertengahan tahun 2000 ini ada sekitar 25 (duapuluh lima) organisasi profesi pers. Organisasi tersebut hampir seluruhnya muncul pada momentum euforia reformasi. Namun hanya ada beberapa yang dapat bertahan dalam arti melaksanakan aktivitas layaknya organisasi.
} 
merasa dirugikan dan merasa tidak puas atas putusan yang dijatuhkan oleh organisasi profesi tetap tidak tertutup kemungkinannya menyelesaikan secara hukum baik pidana maupun perdata. Namun sangat diharapkan dengan mekanisme-yang telah disediakan di luar jalur hukum formal kiaim dari konsumen pers dapat diselesaikan. Sebab pemănfaatan upaya ini, misalnya dengan Hak Jawab, melalui lembaga internal seperti Ombudsmen dan sebagainya tidak akan mempepanjang friksi dan konflik. Para pihak tidak ada yang merasa menang atau dimenangkan, merasa kalah atau dikalahkan.

\section{Simpulan}

Berdasarkan uraian di atas nyata bahwa untuk konsumen pers tidak benar kalau dasar gugatannya adalah UUPK. Dalam hal ini UU Pers telah memberikan rumusan yang cukup jelas tentang bagaimana dan apa saja yang termasuk di dalam tanggung jawab pers. Atas dasar itu pula, konsumen pers dapat melakukan tuntutan pidana dan atau gugatan perdata atas sajian pers yang dianggap menimbulkan kerugian berdasarkan UU No. 40 tahun 1999 tersebut dan tidak atas dasar UUPK.

\section{Daftar Pustaka}

Abdullah, Mustafa. 1998. "Sistem Pertanggungjawaban Pidana Pers Menurut Hukum Positif di Indonesia." Pidato Pengukuhan Guru Besar FH Universitas Sriwijaya.Palembang. Universitas Sriwijaya.
Aliansi Jurnalis Independen.1998. Pers: Diterpa Krisis. Jakarta: AJI-LSPP.

Brotosusilo, Agus. 1998. Perlindungan Terhadap Konsumen dalam Sistem Hukum di Indonesia, Makalah: Jakarta: YLKI-USAID

Hadjon, Philipus M: 1987. Perlindungan. Hukum Bagi Rakyat di -Indonesia. Surabaya: Bina limu.

_- 1994. Pengkajian IImu Hukum Dogmatik (Normatif). Surabaya: Fakultas Hukum Unair.

Rasyidi, Lili. IB. Wiyasa Putra. 1993. Hukum Sebagai Suatu Sistem. Bandung. Remaja Roosdakarya.

Sumarwan, Ujang. 1998. "Masalah Keamanan

Pangan dalam Pola Konsumsi Masyarakat Indonesia." Makalah. Jakarta. YLKI-USAID.

Sutomo, M. Said. 2000. "Hak Gugat Konsumen terhadap Perilaku Usaha Pers." Harian Surya Surabaya. Rabu 28 Juni 2000.

Wahidin, Samsul. 1999. "Tanggung Jawab Atas Pemberitaann Pers Dalam Media Cetak." Disertasi. Surabaya. PPS Unair.

- 2000. "Tanggungjawab Hukum Atas Sajian Pers Surabaya." Surat Kabar Harian Surya.

2000. "Perspektif Hukum Tanggung Jawab Pers." Makalah disampaikan pada Seminar Pers-YLKI. Banjarmasin. 20 Juni 2000. 